\title{
SYNTHESIS OF NOVEL OLIGOMERIC POLYOLS FROM EPOXIDISED METHYL OLEATE AND EPOXIDISED PALM OLEIN FOR ELASTIC POLYURETHANE PRODUCTS
}

\author{
HOONG SENG SOI *; YEONG SHOOT KIAN* and ZAINAB IDRIS*
}

\begin{abstract}
Novel oligomeric polyols were synthesised from epoxidised methyl oleate (EMO) and epoxidised palm olein (EPOo) through epoxide ring opening polymerisation catalysed by boron trifluoride diethyl etherate $\left(B F_{3}\right.$. $E t_{2} \mathrm{O}$ ). The properties of these oligomeric polyols were affected by the degree of epoxide of the feedstock as well as reaction conditions (monomer concentration, catalyst amount, reaction temperature and duration). Gel permeation chromatography (GPC) analysis showed that the oligomeric content of the synthesised oligomeric polyols were in the range of $85 \%-90 \%$ and the number average molecular weight $\left(M_{n}\right)$ of the oligomeric polyols were between $1900 \mathrm{Da}$ and $16100 \mathrm{Da}$ depending on the feedstock. In addition, mass spectrometry, Matrix-assisted laser desorption/ionisation-time of flight (MALDI-TOF) and nuclear magnetic resonance (NMR) analyses revealed that the oligomeric polyols were dimer and higher oligomers of feedstock linked by ether groups. These oligomeric polyols have desirable low acid values, which were less than $1 \mathrm{mg} \mathrm{KOH} \mathrm{g-1}$ and hydroxyl values in between 35 to $45 \mathrm{mg} \mathrm{KOH} \mathrm{g}^{-1}$. The oligomeric polyols made from EPOo was mixed with polyethylene glycol (PEG 3350) and reacted with diisocyanate to form polyurethane (PU) sample with good elastomeric properties.
\end{abstract}

Keywords: renewable resources, epoxidation, oxirane ring opening.

Date received: 13 June 2017; Sent for revision: 13 June 2017; Received in final form: 24 July 2017; Accepted: 28 July 2017.

\section{INTRODUCTION}

The desires to lower the dependence on depleting fossil fuels have been driving the development of sustainable chemicals from renewable resources (Huber etal., 2005; Ragauskas etal., 2006). Historically, vegetable oil is one of the major renewable resources used by chemical industries in various applications (Baumann et al., 1988). One particular application is its use in polymers, where there have been many studies on the synthesis and characterisation of

* Malaysian Palm Oil Board, 6 Persiaran Institusi,

Bandar Baru Bangi, 43000 Kajang,

Selangor, Malaysia.

E-mail: sengsoi@mpob.gov.my polymers made from vegetable oils (Meier et al., 2007). An area of interest is in the development of renewable polyols and polyurethanes (PU) from vegetable oils (Desroches et al., 2012). The most common method to make polyols from vegetable oils is through the epoxidation of the vegetable oil's alkene group followed by epoxide ring opening with a nucleophile such as methanol or hydrochloric acid (Guo et al., 2000).

Polyols produced through this common method are mostly monomeric polyols, which are basically a single unit of a polyhydroxylated triacylglycerol molecule that have an average molecular weight of $1000 \mathrm{Da}$. These polyols are suitable for making rigid PU products due to their molecular weight and polyhydroxylated nature, which are similar to 
the properties of typical petroleum-based polyols use for making rigid PU products (Ionescu, 2005). In contrast, typical polyols for elastic PU products have higher molecular weight $(3000-6500 \mathrm{Da})$ and lower hydroxyl functionalities (Ionescu, 2005), which cannot be fulfilled by vegetable oil-based polyols prepared through the method described above. Therefore, a different synthesis method is required to prepare oligomeric polyols from vegetable oils.

Not many literatures have reported on making oligomeric/polymeric polyols from vegetable oil and its derivatives. One of the examples is the work done by Lligadas et al. (2006) where the epoxidised methyl oleate was oligomerised through epoxide ring-opening polymerisation at room temperature by using fluoroantimonic acid $\left(\mathrm{HSbF}_{6}\right)$ as the catalyst. Subsequently, the ester groups of the oligomerised methyl oleate were reduced to hydroxyl groups with lithium aluminium hydride $\left(\mathrm{LiAlH}_{4}\right)$ in tetrahydrofuran (THF) in order to yield oligomeric polyols with 3-4 hydroxyl groups per mol that have molecular weight in the range of 1000 to $1500 \mathrm{Da}$, which are suitable for rigid PU.

Epoxide ring opening polymerisation had also been performed on epoxidised vegetable oils. For example, Liu et al. (2010) reported the epoxide ring opening polymerisation of epoxidised soyabean oil in dichloromethane catalysed by boron trifluoride diethyl etherate $\left(\mathrm{BF}_{3} \cdot \mathrm{Et}_{2} \mathrm{O}\right)$ at $0^{\circ} \mathrm{C}$ for $3 \mathrm{hr}$. Products from this reaction were cross-linked polymers, which were insoluble in many common solvents. These cross-linked polymers were hydrolysed to make hydrogels for pharmaceutical applications. However, these cross-linked polymers are not suitable for making PU products due to their crosslinked nature. Therefore, the objective of this study is to synthesise oligomeric polyols from epoxidised palm oil derivatives, namely epoxidised methyl oleate (EMO) and epoxidised palm olein (EPOo), through epoxide ring opening oligomerisation in the presence of boron trifluoride diethyl etherate $\left(\mathrm{BF}_{3} \cdot \mathrm{Et}_{2} \mathrm{O}\right)$ without forming cross-linked polymers. Another aim of this study is to evaluate the mechanical properties of PU samples made from the prepared oligomeric polyols in order to assess their appropriate application in PU products.

\section{MATERIALS AND METHODS}

\section{Materials}

All purchased chemicals reagents were used as received. The following chemicals were purchased from the sources indicated: palm olein (POo) (Southern Edible Oil, Klang, Selangor, Malaysia), hydrogen peroxide (30\% in water, Fisher Scientific, Loughborough, UK). Tungsten powder $(12 \mu \mathrm{m}$,
$99.99 \%)$, methyl oleate $(\mathrm{MO})(70 \%)$, phase transfer catalyst Adogen 464, boron trifluoride diethyl etherate $(48 \% \mathrm{w} / \mathrm{v})$, polyethylene glycol (PEG) average $M_{n} 3350$ and 4,4'-methylene diphenyl diisocyanate (MDI) were supplied by Sigma Aldrich (St. Louis, MO, USA).

\section{Synthesis of Epoxidised Methyl Oleate (EMO)}

Tungsten powder $(12 \mu \mathrm{m}, 99.99 \%, 6.8 \mathrm{~g}, 37$ $\mathrm{mmol})$, hydrogen peroxide $(30 \%, 50 \mathrm{~g}, 440 \mathrm{mmol})$ and deionised water $(30 \mathrm{ml})$ were charged into a round bottom flask equipped with a magnetic stirrer and reflux condenser. The mixture was stirred and heated up to $50^{\circ} \mathrm{C}$ until the tungsten powder was totally dissolved, then phosphoric acid $\left(\mathrm{H}_{3} \mathrm{PO}_{4}\right)(85 \%, 0.26 \mathrm{~g}, 2.24 \mathrm{mmol})$ in water $(30$ $\mathrm{ml}$ ) was added into it (this is the tungsten catalyst solution). MO (100 g, $338 \mathrm{mmol}$ ) and Adogen 464 $(0.45 \mathrm{~g}, 0.97 \mathrm{mmol})$ were charged into another threeneck round bottom flask equipped with a motor stirrer. The mixture was heated to $50^{\circ} \mathrm{C}$ and stirred vigorously. The tungsten catalyst solution was added to the mixture followed by deionised water $(50 \mathrm{ml})$, hydrogen peroxide $(30 \%, 65 \mathrm{~g}, 570 \mathrm{mmol})$. The temperature of the reaction mixture was kept at $70^{\circ} \mathrm{C}$ for $3 \mathrm{hr}$. The reaction mixture was then poured into a separating funnel, and then saturated sodium chloride $(\mathrm{NaCl})$ solution $(100 \mathrm{ml})$ and diethyl ether $(100 \mathrm{ml})$ were added to the reaction mixture. The aqueous layer was separated from the organic layer and the organic layer was neutralised with saturated sodium hydrogen carbonate solution $(50 \mathrm{ml})$ followed by washing with $\mathrm{NaCl}$ solution $(100 \mathrm{ml})$. The organic layer was then dried over anhydrous magnesium sulphate $\left(\mathrm{MgSO}_{4}\right)$ followed by removal of solvent in vacuo to yield EMO (97 $\mathrm{g}$, $311 \mathrm{mmol}, 92 \%$ yield), which was a colourless liquid. The $v_{\max } / \mathrm{cm}^{-1} 2924,2855(\mathrm{C}-\mathrm{H}) 1740(\mathrm{C}=\mathrm{O})$ 1170 (C-O) 825 (C-O-C) $723\left(\mathrm{CH}_{2}\right) ;{ }^{1} \mathrm{H}$ NMR $(400$ $\left.\mathrm{MHz}, \mathrm{CDCl}_{3}\right): \delta_{\mathrm{H}}=3.60\left(3 \mathrm{H}, \mathrm{s}, \mathrm{CH}_{3} \mathrm{O}\right), 3.20-2.80$ $\left(2 \mathrm{H}, \mathrm{m}, \mathrm{CH}_{2} \mathrm{CHOCHCH}_{2}\right), 2.30(2 \mathrm{H}, \mathrm{t}, \mathrm{J}=7.5 \mathrm{~Hz}$, $\left.\mathrm{O}=\mathrm{CC}_{2} \mathrm{CH}_{2}\right), 1.67-1.54\left(2 \mathrm{H}, \mathrm{m}, \mathrm{O}=\mathrm{CCH}_{2} \underline{\mathrm{CH}}_{2} \mathrm{CH}_{2}\right)$, 1.54-1.40 $\left(4 \mathrm{H}, \mathrm{m}, \mathrm{CHOCH}_{2} \mathrm{CH}_{2}\right), 1.37-1.15(22 \mathrm{H}, \mathrm{m}$, $\left.\mathrm{C}_{2} \mathrm{CH}_{2}\right), 0.87\left(3 \mathrm{H}, \mathrm{t}, J=7.5 \mathrm{~Hz}, \mathrm{CH}_{2} \mathrm{CH}_{3}\right){ }^{13} \mathrm{C} \mathrm{NMR}$ $\left(100 \mathrm{MHz} \mathrm{CDCl}_{3}\right): \delta_{\mathrm{C}}=174.1(\mathrm{MeOC}=\mathrm{O}), 56.8-57.1$ $\left(\mathrm{CH}_{2} \underline{\mathrm{CHOC}} \underline{\mathrm{CHCH}}{ }_{2}\right), 51.2\left(\mathrm{CH}_{3} \mathrm{O}\right), 33.7\left(\mathrm{O}=\mathrm{CCl}_{2} \mathrm{CH}_{2}\right)$, 31.8-28.9 $\left(\mathrm{CH}_{2} \mathrm{CH}_{2}\right), \quad 27.7\left(\mathrm{CHOCH}_{2} \mathrm{CH}_{2}\right), \quad 24.8$ $\left(\mathrm{O}=\mathrm{CCH}_{2} \underline{\mathrm{CH}}_{2} \mathrm{CH}_{2}\right), 22.5\left(\mathrm{CH}_{2} \mathrm{CH}_{3}\right), 13.9\left(\mathrm{CH}_{2} \mathrm{CH}_{3}\right)$; $\mathrm{m} / z\left(\mathrm{ES}^{+}\right)\left[\mathrm{M}+\mathrm{Na}^{+}\right]$required 335.25 , found 335.25

\section{Synthesis of Epoxidised Palm Olein (EPOo)}

The experimental trial was conducted according to the procedure described for the synthesis of EMO. Tungsten powder $(12 \mu \mathrm{m}, 99.99 \%, 1.8 \mathrm{~g}, 9.8$ $\mathrm{mmol})$, hydrogen peroxide $(30 \%, 24 \mathrm{~g}, 211 \mathrm{mmol})$, deionised water $(6 \mathrm{ml}), \mathrm{H}_{3} \mathrm{PO}_{4}(85 \%, 1.2 \mathrm{~g}, 10.4$ $\mathrm{mmol})$ in water $(12 \mathrm{ml})$, palm olein (POo) $(300 \mathrm{~g}, 350$ 
mmol), Adogen 464 (2.4 g, $5.17 \mathrm{mmol})$, water (480 $\mathrm{ml})$, hydrogen peroxide $(30 \%, 180 \mathrm{~g}, 1588 \mathrm{mmol})$, saturated $\mathrm{NaCl}$ solution $(200 \mathrm{ml})$, diethyl ether (300 $\mathrm{ml})$, saturated sodium hydrogen carbonate solution $(100 \mathrm{ml}), \mathrm{NaCl}$ solution $(200 \mathrm{ml})$, EPOo $(296 \mathrm{~g}, 333$ mmol, 95\% yield), which was a pale yellow liquid. The $v_{\max } / \mathrm{cm}^{-1} 2923,2854(\mathrm{C}-\mathrm{H}) 1742(\mathrm{C}=\mathrm{O}) 1464$ $\left(\mathrm{CH}_{2}\right) 1158$ and $1111(\mathrm{C}-\mathrm{O}) 821(\mathrm{C}-\mathrm{O}-\mathrm{C}) 722\left(\mathrm{CH}_{2}\right)$; ${ }^{1} \mathrm{H}$ NMR $\left(400 \mathrm{MHz}, \mathrm{CDCl}_{3}\right): \delta_{\mathrm{H}}=5.28-5.21(1 \mathrm{H}$, m, C $\left.4.13 \overline{(2 \mathrm{H}}, \mathrm{dd}, \mathrm{J}=11.9 \mathrm{~Hz}, 5.9 \mathrm{~Hz}, \mathrm{C}_{2} \mathrm{O}\right), 3.10-2.80$ $\left(4 \mathrm{H}, \mathrm{m}, \mathrm{CH}_{2} \mathrm{CHOCHCH}_{2}\right), 2.30(6 \mathrm{H}, \mathrm{t}, J=7.5 \mathrm{~Hz}$, $\left.\mathrm{O}=\mathrm{CCH}_{2} \mathrm{CH}_{2}\right), 1.65-1.55\left(6 \mathrm{H}, \mathrm{m}, \mathrm{O}=\mathrm{CCH}_{2} \underline{\mathrm{CH}}_{2} \mathrm{CH}_{2}\right)$, $1.55-1.42\left(8 \mathrm{H}, \mathrm{m}, \mathrm{CHOC} \underline{\mathrm{H}}_{2} \mathrm{CH}_{2}\right), 1.42-1.20(64 \mathrm{H}, \mathrm{m}$, $\mathrm{CH} 2 \mathrm{CH} 2), 0.89$ (9H, t, $\left.J=7.5 \mathrm{~Hz} \mathrm{C \underline {H } _ { 2 }} \mathrm{CH}_{3}\right) ;{ }^{13} \mathrm{C} \mathrm{NMR}$ $\left(100 \mathrm{MHz} \mathrm{CDCl}_{3}\right): \delta_{\mathrm{C}}=172.9,172.5(\underline{\mathrm{C}}=\mathrm{O}), 68.8$ (Hㄷ-O), 61.8, $\left.61.5\left(\mathrm{H}_{2} \mathrm{C}-\mathrm{O}\right), 56.5\left(\mathrm{CH}_{2} \underline{\mathrm{CHOCHCH}}\right)\right)$, $33.7\left(\mathrm{O}=\mathrm{CCH}_{2} \mathrm{CH}_{2}\right), \quad 29.4-22.4 \quad\left(\underline{\mathrm{CH}}_{2} \mathrm{CH}_{2}\right), \quad 28.9$ $\left(\mathrm{CHOCH}_{2} \mathrm{CH}_{2}\right), \quad 27.8 \quad\left(\mathrm{O}=\mathrm{CCH}_{2} \underline{\mathrm{CH}}_{2} \mathrm{CH}_{2}\right), \quad 13.8$ $\left(\mathrm{CH}_{2} \underline{\mathrm{CH}}_{3}\right) ; m / z\left(\mathrm{ES}^{+}\right)\left[\mathrm{M}+\mathrm{Na}^{+}\right]$required 913.74 , found 913.74

\section{Oligomerisation of EMO Catalysed by $\mathrm{BF}_{3} \cdot \mathrm{Et}_{2} \mathrm{O}$}

EMO (100 g, $320 \mathrm{mmol})$ was weighed into a round bottom flask and hexane $(200 \mathrm{ml})$ was added to it. The reactants mixture was stirred and heated at $20^{\circ} \mathrm{C}$ under $\mathrm{N}_{2}$ atmosphere for $30 \mathrm{~min}$ before $\mathrm{BF}_{3} \cdot \mathrm{Et}_{2} \mathrm{O}(2.3 \mathrm{~g}, 16 \mathrm{mmol})$ was added drop-wise to $(\mathrm{EMO})$. After completing the addition of $\mathrm{BF}_{3}$. $\mathrm{Et}_{2} \mathrm{O}$, the reaction temperature was maintained at $25^{\circ} \mathrm{C}$ for another $24 \mathrm{hr}$. Then, the reaction mixture was poured into a separation funnel and washed with sodium bicarbonate solution $(250 \mathrm{ml})$. The aqueous layer was separated from the organic layer and chloroform $\left(\mathrm{CHCl}_{3}\right)(500 \mathrm{ml})$ was added to the organic layer. The organic layer was dried over anhydrous $\mathrm{MgSO}_{4}$ and organic solvents were removed in vacuo to yield oligomerised methyl oleate polyol (OMOP), which was a yellowish liquid (95.24 g); $v_{\max } / \mathrm{cm}^{-1} 3350(\mathrm{O}-\mathrm{H})$ 2922, 2853 (C-H) 1739 $(\mathrm{C}=\mathrm{O}) 1459\left(\mathrm{CH}_{2}\right) 1169(\mathrm{C}-\mathrm{O}) 723\left(\mathrm{CH}_{2}\right){ }^{1} \mathrm{H}$ NMR $\left(400 \mathrm{MHz}_{\mathrm{CDCl}}\right): \delta_{\mathrm{H}}=3.66(9 \mathrm{H}, \mathrm{s}, \underline{\mathrm{HCO}}), 3.60-3.05$ $(6 \mathrm{H}, \mathrm{m}, \underline{\mathrm{HCO}}), 2.30\left(6 \mathrm{H}, \mathrm{t}, J=7.5 \mathrm{~Hz}, \mathrm{O}=\mathrm{CC}_{2} \mathrm{CH}_{2}\right)$, $1.68-1.56\left(6 \mathrm{H}, \mathrm{m}, \mathrm{O}=\mathrm{CCH}_{2} \underline{\mathrm{CH}}_{2} \mathrm{CH}_{2}\right), 1.55-1.20(72 \mathrm{H}$, $\left.\mathrm{m}, \mathrm{CH}_{2} \underline{\mathrm{CH}}_{2} \mathrm{CH}_{2}\right), 0.87\left(9 \mathrm{H}, \mathrm{t}, J=7.5 \mathrm{~Hz}, \mathrm{CH}_{2} \mathrm{CH}_{3}\right)$; ${ }^{13} \mathrm{C}$ NMR (100 MHz $\left.\mathrm{CDCl}_{3}\right): \delta_{\mathrm{C}}=173.9(\mathrm{C}=\mathrm{O}) 74.1$, $73.4,71.7(\mathrm{C}-\mathrm{O}), 58.8\left(\mathrm{OCH}_{3}\right) 33.6\left(\mathrm{O}=\mathrm{CCCH}_{2}\right), 24.5$ $\left(\mathrm{O}=\mathrm{CCH}_{2} \mathrm{CH}_{2} \mathrm{CH}_{2}\right), 29.3,28.9,22.6\left(\mathrm{CH}_{2} \mathrm{CH}_{2} \mathrm{CH}_{2}\right)$, $13.7\left(\mathrm{CH}_{2} \mathrm{CH}_{3}\right) ; \mathrm{m} / z\left(\mathrm{ES}^{+}\right)\left[\mathrm{M}+\mathrm{Na}^{+}\right]$required 977.79, found 977.79

\section{Oligomerisation of EPOo Catalysed by $\mathrm{BF}_{3} . \mathrm{Et}_{2} \mathrm{O}$}

The experimental trial was conducted according to the procedure described for the oligomerisation of EMO. EPOo (100 g, $112 \mathrm{mmol})$, hexane $(600 \mathrm{ml})$, $\mathrm{BF}_{3} \cdot \mathrm{Et}_{2} \mathrm{O}(1.1 \mathrm{~g}, 7.8 \mathrm{mmol})$, sodium bicarbonate solution $(250 \mathrm{ml}), \mathrm{CHCl}_{3}(500 \mathrm{ml})$, oligomerised palm olein polyol (OPOoP), which was a yellowish liquid (98.4 g); vmax/ cm $3348(\mathrm{O}-\mathrm{H})$ 2921, 2851 (C-H) $1742(\mathrm{C}=\mathrm{O}) 1459\left(\mathrm{CH}_{2}\right) 1158(\mathrm{C}-\mathrm{O}) 722\left(\mathrm{CH}_{2}\right)$ ${ }^{1} \mathrm{H}$ NMR $\left(400 \mathrm{MHz}, \mathrm{CDCl}_{3}\right): \delta \mathrm{H}=5.22-5.13(1 \mathrm{H}, \mathrm{m}$, C $\underline{\mathrm{HO}}), 4.21\left(2 \mathrm{H}, \mathrm{dd}, J=11.9 \mathrm{~Hz}, 4.1 \mathrm{~Hz}, \mathrm{CH}_{2} \mathrm{O}\right), 4.07$ $\left(2 \mathrm{H}, \mathrm{dd}, J=11.8 \mathrm{~Hz}, 5.9 \mathrm{~Hz}, \mathrm{CH}_{2} \mathrm{O}\right), 3.80-3.00(4 \mathrm{H}$, $\mathrm{m}, \underline{\mathrm{HCO}}), 2.23\left(6 \mathrm{H}, \mathrm{t}, J=7.5 \mathrm{~Hz}, \mathrm{O}=\mathrm{CC}_{2} \mathrm{CH}_{2}\right), 1.60-$ $1.47\left(6 \mathrm{H}, \mathrm{m}, \mathrm{O}=\mathrm{CCH}_{2} \mathrm{CH}_{2} \mathrm{CH}_{2}\right), 1.35-1.10(64 \mathrm{H}, \mathrm{m}$, $\left.\mathrm{CH}_{2} \mathrm{CH}_{2}\right), 0.79\left(9 \mathrm{H}, \mathrm{t}, \mathrm{J}=7.5 \mathrm{~Hz}, \mathrm{CH}_{2} \mathrm{CH}_{3}\right) ;{ }^{13} \mathrm{C} \mathrm{NMR}$ $\left(100 \mathrm{MHz} \mathrm{CDCl}_{3}\right): \delta_{\mathrm{C}}=173.2,172.5(\mathrm{C}=\mathrm{O}) 72.4(\mathrm{HC}-$ O) $68.8(\mathrm{HC}-\mathrm{O}), 61.8,61.6\left(\mathrm{H}_{2} \underline{\mathrm{C}}-\mathrm{O}\right), 33.9\left(\mathrm{O}=\mathrm{CCCH}_{2}\right)$, $24.7\left(\mathrm{O}=\mathrm{CCH}_{2} \mathrm{CH}_{2} \mathrm{CH}_{2}\right), 29.5,22.7\left(\mathrm{CH}_{2} \mathrm{CH}_{2} \mathrm{CH}_{2}\right)$, $13.9\left(\mathrm{CH}_{2} \underline{\mathrm{CH}_{3}}\right)$.

\section{General Procedure for the Preparation of PU from} Oligomeric Polyols

Preparation of polyurethane (OPOoP-MDI) from oligomeric polyol (OPOoP) as example. OPOoP (10 g, hydroxyl value $=45 \mathrm{mg} \mathrm{KOH} \mathrm{g}^{-1}$ sample) was weighed into a round bottom flask and chloroform ( $20 \mathrm{ml}$ ) was added to dissolve it. The round bottom flask was purged with dry nitrogen gas to remove any moisture from the system. Then, 4,4'- MDI (0.9 g) was added to the dissolved polyol. The NCO/ $\mathrm{OH}$ ratio index was 1.02. The reaction mixture was heated to $60^{\circ} \mathrm{C}$ for $24 \mathrm{hr}$. After $24 \mathrm{hr}$, some of the chloroform was removed using a rotary evaporator and then PU product was poured into a pre-heated mold at $60^{\circ} \mathrm{C}$. The PU (OPOoP-MDI) was cured at $60^{\circ} \mathrm{C}$ for $24 \mathrm{hr}$ in an oven. The $v_{\max } / \mathrm{cm}^{-1} 2916,2849$ (C-H) $1725(\mathrm{C}=\mathrm{O}) 1530$ (aromatic=CH) $1173(\mathrm{C}-\mathrm{O})$ $721\left(\mathrm{CH}_{2}\right)$.

\section{General Procedure for the Preparation of PU from Oligomeric Polyols and Polyethylene Glycol}

Preparation of PU (OPOoP-PEG-MDI) from oligomeric polyols (OPOoP) and PEG as example. The experimental trial was conducted according to the procedure described for the preparation of PU (OPOoP-MDI). Oligomeric polyol (OPOoP) (5 g, hydroxyl value $=45 \mathrm{mg} \mathrm{KOH} \mathrm{g}^{-1}$ sample), PEG (average molecule weight $=3350 \mathrm{Da})(6.5 \mathrm{~g})$, chloroform (25 ml), 4,4'-MDI (1.7 g). The $v_{\max } / \mathrm{cm}^{-1}$ 2922, 2853 (C-H) 1743 (C=O) 1597 (aromatic=CH) 1095 (C-O) $721\left(\mathrm{CH}_{2}\right)$.

\section{Characterisation}

Infra-red spectra were recorded as solid or liquid on Perkin-Elmer Spectrum100 FTIR spectrometer and the absorption maxima $\left(v_{\max }\right)$ are recorded in wavenumbers $\left(\mathrm{cm}^{-1}\right)$. Solids were compressed into a thin tablet and non-volatile liquids were analysed as thin film over diamond attenuated total reflectance (ATR) top plate.

Mass spectrometry of low resolution was recorded on Bruker Esquire ESI 2000 in which 
molecular ions, fragment ions and other major peaks are recorded as mass/charge $(\mathrm{m} / \mathrm{z})$ ratios. High resolution mass spectrometry was achieved using Bruker MaXis instrument to carry out accurate mass analysis. Proton $\left({ }^{1} \mathrm{H}\right)$ and carbon $\left({ }^{13} \mathrm{C}\right)$ nuclear magnetic resonance (NMR) spectroscopy were recorded on Bruker DPX-400 at $400 \mathrm{MHz}$ and $100 \mathrm{MHz}$ respectively at $298 \mathrm{~K}$ with approximately $10 \% \mathrm{w} / \mathrm{v}$ solutions in deuterated NMR solvents. Chemical shifts are quoted in $\mathrm{ppm}$ relative to internal standard tetramethylsilane (TMS) and reference to the residual solvent. All coupling constant are quoted in hertz $(\mathrm{Hz})$. The ${ }^{1} \mathrm{H}$ and ${ }^{13} \mathrm{C}$ NMR assignments were routinely confirmed by ${ }^{1} \mathrm{H}$ ${ }^{1} \mathrm{H}(\mathrm{COSY})$ and ${ }^{1} \mathrm{H}-{ }^{13} \mathrm{C}$ (HMQC) data.

Matrix-assisted laser desorption/ionisationtime of flight mass spectrometry (MALDI-TOFMS) measurement was performed with a Bruker Daltonics Ultraflex II TOF/TOF mass spectrometer equipped with a nitrogen laser delivering 3-ns laser pulses at $337 \mathrm{~nm}$. Sample of $5 \mathrm{mg}$ was dissolved in $100 \mu \mathrm{l}$ tetrahydrofuran and $50 \mathrm{mg}$ of 2,5-dihydroxybenzoic acid (DHB) as the matrix was dissolved in $200 \mu \mathrm{l}$ tetrahydrofuran. Sample solution $(5 \mu \mathrm{l})$ and matrix solution $(20 \mu \mathrm{l})$ were mixed and $0.5 \mu$ l of this mixture was spotted on the target plate and analysed. The sample was irradiated with 300-600 pulsed laser shots at a 20\% laser power and was measured in reflectron ion mode and was calibrated against poly (ethylene glycol) methyl ether.

Gel permeation chromatography (GPC) with THF as the eluent was performed on an Agilent 390MDS that has an autosampler and a PLgel $5.0 \mu \mathrm{m}$ bead-size guard column $(50 \times 7.5 \mathrm{~mm})$, followed by two linear $5.0 \mu \mathrm{m}$ bead-size PLgel Mixed D columns $(300 \times 7.5 \mathrm{~mm})$ and a differential refractive index detector. Analysis was performed using THF (2\% $\mathrm{v} / \mathrm{v}$ triethylamine) as the eluent at $30^{\circ} \mathrm{C}$ with a flow rate of $1 \mathrm{ml} \mathrm{min}^{-1}$. The GPC system was calibrated using linear poly(methyl methacrylate) (PMMA) EasiVial standards (Agilent Ltd) range from 200 to $10^{5} \mathrm{Da}$ and polystyrene (PS) EasiVial standards (Agilent Ltd) range from 162 to $10^{5} \mathrm{Da}$. Data were collected and analysed using Cirrus GPC/SEC software (version 3.3).

Wet chemical analysis was performed according to the AOCS Official Methods (AOCS, 2009): acid value $(\mathrm{AV}), \mathrm{Te} 1 \mathrm{a}-64$; hydroxyl value $(\mathrm{OHV}), \mathrm{Cd}$ I360; oxirane oxygen content, Cd 9-57.

Tensile strength and elongation at break of PU samples were determined according to EN ISO 529-4: 1997 (CEN1997a). This is the European Standard Test Method for the determination of tensile properties of polymeric materials. Testing was conducted with an Instron 5800 universal testing machine with an initial cross-head speed of $1 \mathrm{~mm} \mathrm{~min}^{-1}$ for $2 \mathrm{~min}$ and then $50 \mathrm{~mm} \mathrm{~min}^{-1}$. The test specimens were of the type 1BA.

\section{RESULTS AND DISCUSSION}

\section{Synthesis of Oligomeric Polyols and PU from POo and MO}

POo was subjected to epoxidation reaction according to a procedure reported by Coles et al. (2008) to produce EPOo. The yield of EPOo was determined by GPC and ${ }^{1} \mathrm{H}$ NMR analysis. The oxirane oxygen content (OOC) of the prepared EPOo was 3.3\%. Subsequently, the prepared EPOo was dissolved in n-hexane and $\mathrm{BF}_{3} \cdot \mathrm{Et}_{2} \mathrm{O}$ was added to the reaction mixture to catalyse the epoxide ring opening reaction that yielded OPOoP. The OOC of the prepared OPOoP was less than $0.1 \%$. Then, the prepared OPOoP was reacted with 4, $4^{\prime}$-MDI to form PU sample. The overall synthesis of OPOoP and PU from POo can be illustrated by Figure 1.

Similarly, MO was subjected to the same synthetic steps to yield oligomeric methyl oleate polyol (OMOP) and PU sample (OMOP-MDI) as shown in Figure 2. The OOC of prepared EMO was $4.9 \%$ while the OOC of synthesised OMOP was less than $0.1 \%$, which showed that all the epoxide group of EMO was ring opened during the reaction to yield OMOP.

\section{Effect of Monomer Concentration on the Properties of OPOoP}

For this study, EPOo was used as the starting material for epoxide ring opening oligomerisation in hexane at $25^{\circ} \mathrm{C}$, catalysed by $\mathrm{BF}_{3} \cdot \mathrm{Et}_{2} \mathrm{O}$. The first reaction parameter investigated was the concentration of reactant and its effect on the properties of OPOoP. The concentration of the reactant used in the epoxide ring opening reaction was varied in order to observe changes in the properties of the OPOoP. Table 1 shows the properties of oligomeric polyols made from EPOo and EMO.

Referring to Table 1, when the epoxide ring opening oligomerisation reaction was conducted at concentration $3.75 \times 10^{-4} \mathrm{~mol} \mathrm{ml}^{-1}$ and $0.0375 \mathrm{~mol}$ equivalent of $\mathrm{BF}_{3} . \mathrm{Et}_{2} \mathrm{O}$ (Entry 1), the product was a cross-linked (gelled) polymer. However, when the reaction was repeated at lower concentration (1.87 $\times 10^{-4} \mathrm{~mol} \mathrm{ml}^{-1}$ ) (Entry 2 ), the product was a liquid (89\% yield) with number average molecular weight $\left(\mathrm{M}_{\mathrm{n}}\right)$ of $18500 \mathrm{Da}$.

When the same comparison was made $\left(3.75 \times 10^{-4}\right.$ mol ml-1 vs. $1.87 \times 10^{-4} \mathrm{~mol} \mathrm{ml}^{-1}$ ) with a lower amount of catalyst $\left(0.035 \mathrm{~mol}\right.$ equivalent $\mathrm{BF}_{3} \cdot \mathrm{Et}_{2} \mathrm{O}$ ) (Entry 3 and 4 ), the yields of products were similar (90\% vs. $89 \%$ ) but the average molecular weight of OPOoP from reaction conducted at lower concentration (Entry 4) was lower and the PDI was narrower than OPOoP produced from reaction conducted at higher concentration (Entry 3). Thus, higher concentrations of reactant lead to larger molecular weights, more cross-linking and larger PDI's. 
<smiles>CCCCCCCC/C=C\CCCCCCCCC(=O)OCC(COC(=O)CCCCCCCCCCCCC)OC(=O)CCCCCCC/C=C/CCCCCCCC</smiles>

$\mathrm{H}_{2} \mathrm{O}_{2}$, Adogen 464, W, $\mathrm{H}_{3} \mathrm{PO}_{4}$

$70^{\circ} \mathrm{C}, 3 \mathrm{hr}$<smiles>CCCCCCCCCCCCCCCC(=O)OCC(COC(=O)CCCCCCCCC1OC1CCCCCCCC)OC(=O)CCCCCCCC1OC1CCCCCCCC</smiles>

$\mathrm{BF}_{3} \cdot \mathrm{Et}_{2} \mathrm{O}, \mathrm{n}$-hexane

$25^{\circ} \mathrm{C}, 24 \mathrm{hr}$<smiles>CCCCCCCCCCC(=O)OCCCOC(=O)CCCCCCCCC(C)OC(CCCCCCCC)C(O)CCCCCCC</smiles>

$\mathrm{n}=$ number of repeating unit that could be $1,2,3$ or 4

Oligomerised palm olein polyol (OPOoP)

$\mathrm{CHCl}_{3}, 60^{\circ} \mathrm{C}, 24 \mathrm{hr}$

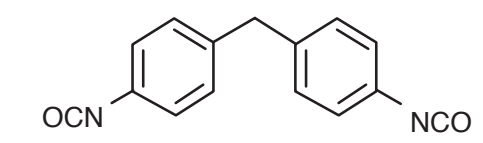

4, 4'-methylene diphenyl diisocyanate (MDI)<smiles>CCCCCCCCCC(=O)OCC(COC(=O)CCCCCCCCC(OC)C(CCCCCCCC)OC(=O)Nc1ccc(Cc2ccc(NC(=O)C(C)C)cc2)cc1)OC(=O)CCCCCCCCC(OC)C(CCCCCCCC)OC(=O)Nc1ccc(Cc2ccc(NC(=O)C(C)C)cc2)cc1</smiles>

Figure 1. Idealised synthesis of oligomerised palm olein polyol (OPOoP) and polyurethane from palm olein. 


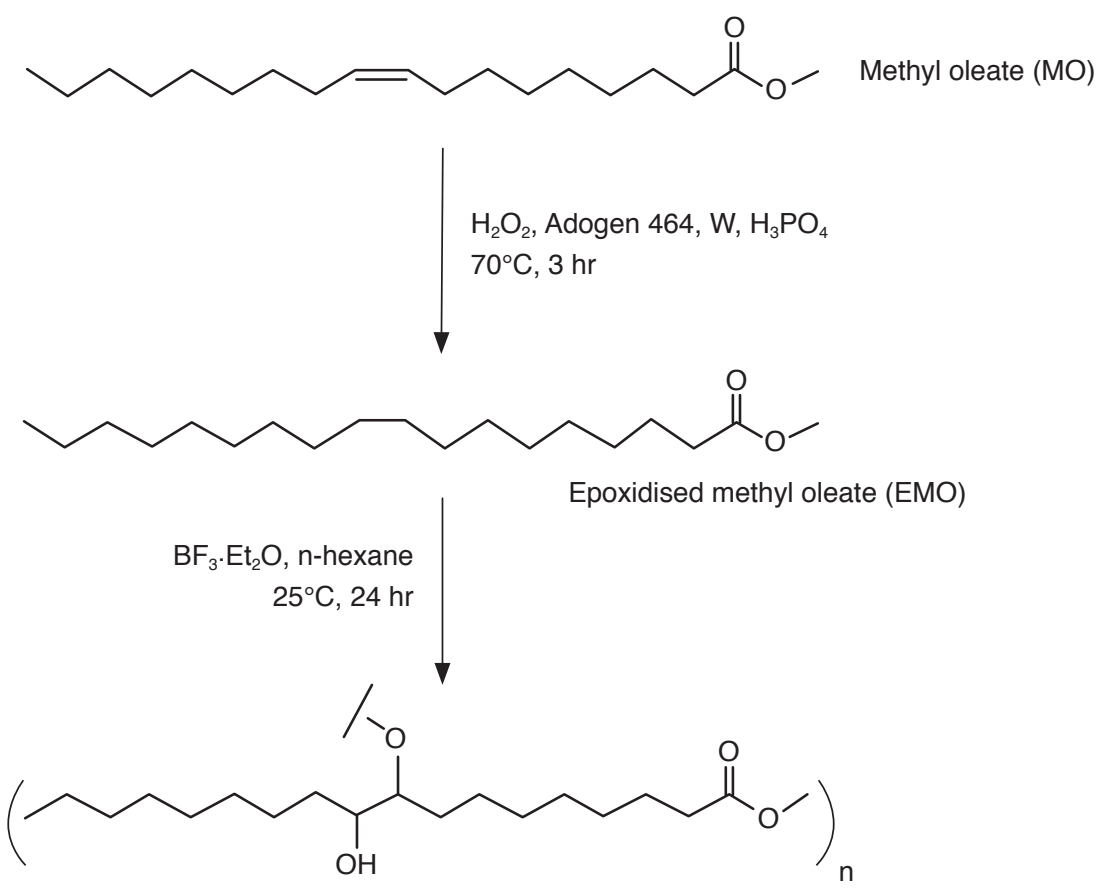

$\mathrm{n}=$ number of repeating unit that could be 1,2 , or 3

Oligomerised methyl oleate polyol (OMOP)

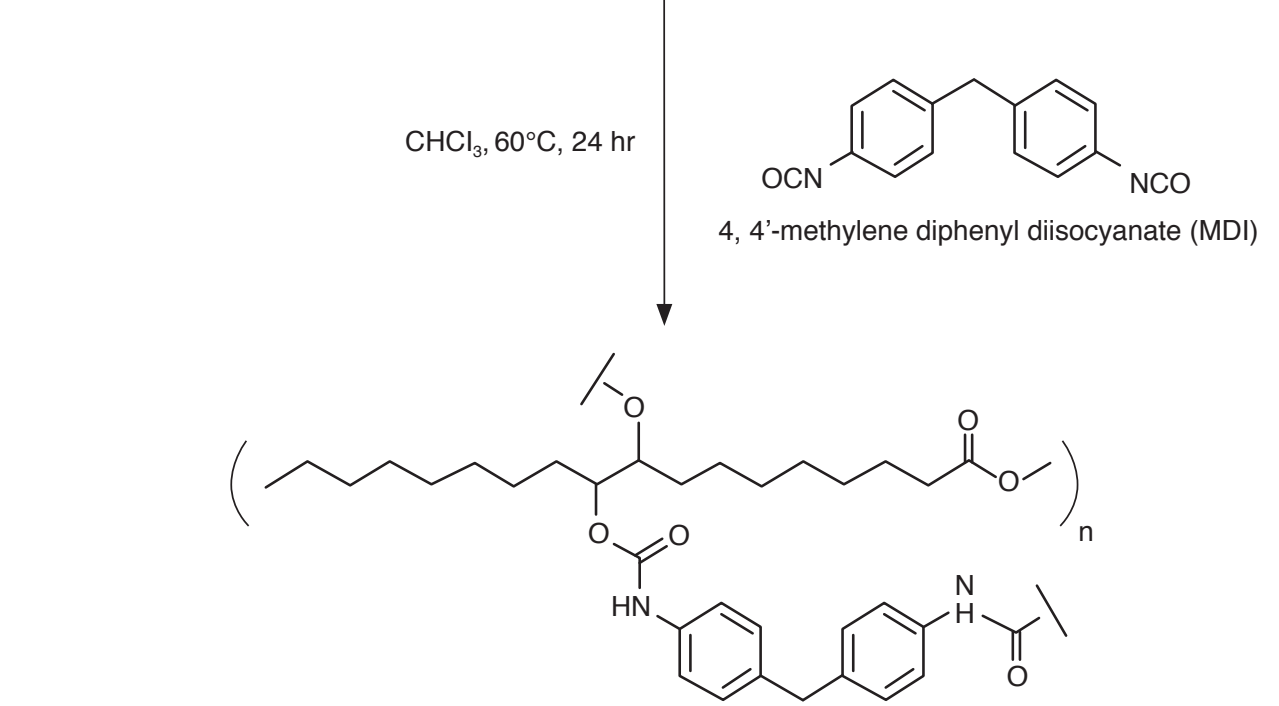

$\mathrm{n}=$ number of repeating unit that could be 1,2 , or 3

Polyurethane (OMOP-MDI)

Figure 2. Idealised synthesis of oligomerised methyl oleate polyol (OMOP) and polyurethane from methyl oleate.

In addition, the amount of catalyst used in the reaction also influences the properties of the products. For example, when reactions were carried out using the same reactant concentration $(3.75 \mathrm{x}$ $10^{-4} \mathrm{~mol} \mathrm{ml}^{-1}$, Entry 1 and 3), the reaction with lower catalyst dosage (Entry 3) yielded liquid product while reaction with higher catalyst dosage (Entry 1) gave gelled product. The same pattern was observed again at lower reactant concentration (Entry 2 and 4). Therefore, lower reactant concentration and lower catalyst dosage will yield OPOoP with lower average molecular weight.

\section{Effect of Reaction Temperature on the Properties of OPOoP}

The epoxide ring opening oligomerisation reaction of EPOo was repeated at different temperatures to evaluate the effect of temperature on the properties of OPOoP. Table 1 tabulates the result of this study.

When the reaction was conducted at $25^{\circ} \mathrm{C}$ with $0.0375 \mathrm{~mol}$ equivalent of $\mathrm{BF}_{3} \cdot \mathrm{Et}_{2} \mathrm{O}$ (Entry 1 ), the product was a cross-linked (gelled) polymer. However, by raising the reaction temperature to 
TABLE 1. PROPERTIES OF OLIGOMERIC POLYOLS MADE FROM EPOXIDISED PALM OLEIN (EPOo) AND EPOXIDISED METHYL OLEATE (EMO)

\begin{tabular}{|c|c|c|c|c|c|c|c|c|}
\hline \multirow[b]{2}{*}{ Entry } & \multirow[b]{2}{*}{ Reactant } & \multirow[b]{2}{*}[\mathrm{T}]{$\left({ }^{\circ} \mathrm{C}\right)$} & \multirow[b]{2}{*}{ [C] } & \multirow[b]{2}{*}{ Mol eq. } & \multirow[b]{2}{*}{ Yield $(\%)$} & \multicolumn{3}{|c|}{ Gel permeation chromatography } \\
\hline & & & & & & $\mathrm{M}_{\mathrm{w}}(\mathrm{Da})$ & $M_{n}(\mathrm{Da})$ & PDI \\
\hline 1 & EPOo & 25 & 3.75 & 0.0375 & Gelled & - & - & - \\
\hline 2 & EPOo & 25 & 1.87 & 0.0375 & 89 & 82600 & 18500 & 4.46 \\
\hline 3 & EPOo & 25 & 3.75 & 0.0350 & 90 & 467000 & 27000 & 17.3 \\
\hline 4 & EPOo & 25 & 1.87 & 0.0350 & 89 & 58200 & 16100 & 3.61 \\
\hline 5 & EPOo & 60 & 3.75 & 0.0375 & 86 & 151000 & 18500 & 8.16 \\
\hline 6 & EPOo & 60 & 3.75 & 0.0350 & 83 & 62600 & 17500 & 3.58 \\
\hline 7 & EMO & 25 & 16 & 0.0300 & 57 & 1500 & 860 & 1.74 \\
\hline 8 & EMO & 25 & 16 & 0.0500 & 85 & 1800 & 1500 & 1.2 \\
\hline 9 & EMO & 25 & 16 & 0.1000 & 85 & 2100 & 1900 & 1.1 \\
\hline
\end{tabular}

Note: $[\mathrm{C}]$ - concentration of reactant $\left(\times 10^{-4} \mathrm{~mol} \mathrm{ml}^{-1}\right)$; Mol eq. - mol equivalent of $\mathrm{BF}_{3} \cdot \mathrm{Et}_{2} \mathrm{O} ;[\mathrm{T}]$ - temperature of reaction; reaction duration - $24 \mathrm{hr} ; \mathrm{M}_{\mathrm{w}}$ - weight average molecular weight; $\mathrm{M}_{\mathrm{n}}$ - number average molecular weight; PDI - polydispersity index

$60^{\circ} \mathrm{C}$ (Entry 5$)$, the product was a liquid ( $86 \%$ yield) with an average molecular weight (Mn) of $18500 \mathrm{Da}$.

When reactions were conducted with a lower amount of catalyst $\left(0.035\right.$ mol equivalent of $\left.\mathrm{BF}_{3} \cdot \mathrm{Et}_{2} \mathrm{O}\right)$ at $25^{\circ} \mathrm{C}$ (Entry 3) and $60^{\circ} \mathrm{C}$ (Entry 6), the OPOoP from $60^{\circ} \mathrm{C}$ exhibited lower average molecular weight and narrower PDI. Therefore, it is apparent that higher reaction temperature promotes chain termination during oligomerisation resulting in smaller molecular weights and narrower molecular weight distribution.

\section{The Extent of Epoxide Ring Opening Oligomerisation Reaction against Time}

A study was conducted to evaluate the extent of epoxide ring opening oligomerisation reaction of EPOo catalysed by $\mathrm{BF}_{3} \cdot \mathrm{Et}_{2} \mathrm{O}$ against time. A small aliquot was removed from the reaction mixture after $30 \mathrm{~min}$ of reaction and then at every hour of reaction. The small sample was washed with water to quench the reaction before analysing it with GPC. Figure 3 shows the result of this study.

Referring to Figure 3, the oligomer content of the reaction mixture reached $82 \%$ at the end of the first 30 min of the reaction, which means that the epoxide ring opening oligomerisation reaction happened rapidly as soon as the $\mathrm{BF}_{3} \cdot \mathrm{Et}_{2} \mathrm{O}$ was added to the reaction mixture. It took a further $12 \mathrm{hr}$ to increase the oligomer content to $91 \%$ and at the same time the PDI of the product also broadened, indicating more polymer chains were cross-linked with the longer reaction time. The $\mathrm{M}_{\mathrm{n}}$ of OPOoP after $24 \mathrm{hr}$ reaction was $16500 \mathrm{Da}$, which correspond to about 11 units of EPOo linked by an ether functionality (taking one unit of EPOo as $1500 \mathrm{Da}$ as analysed by GPC). The

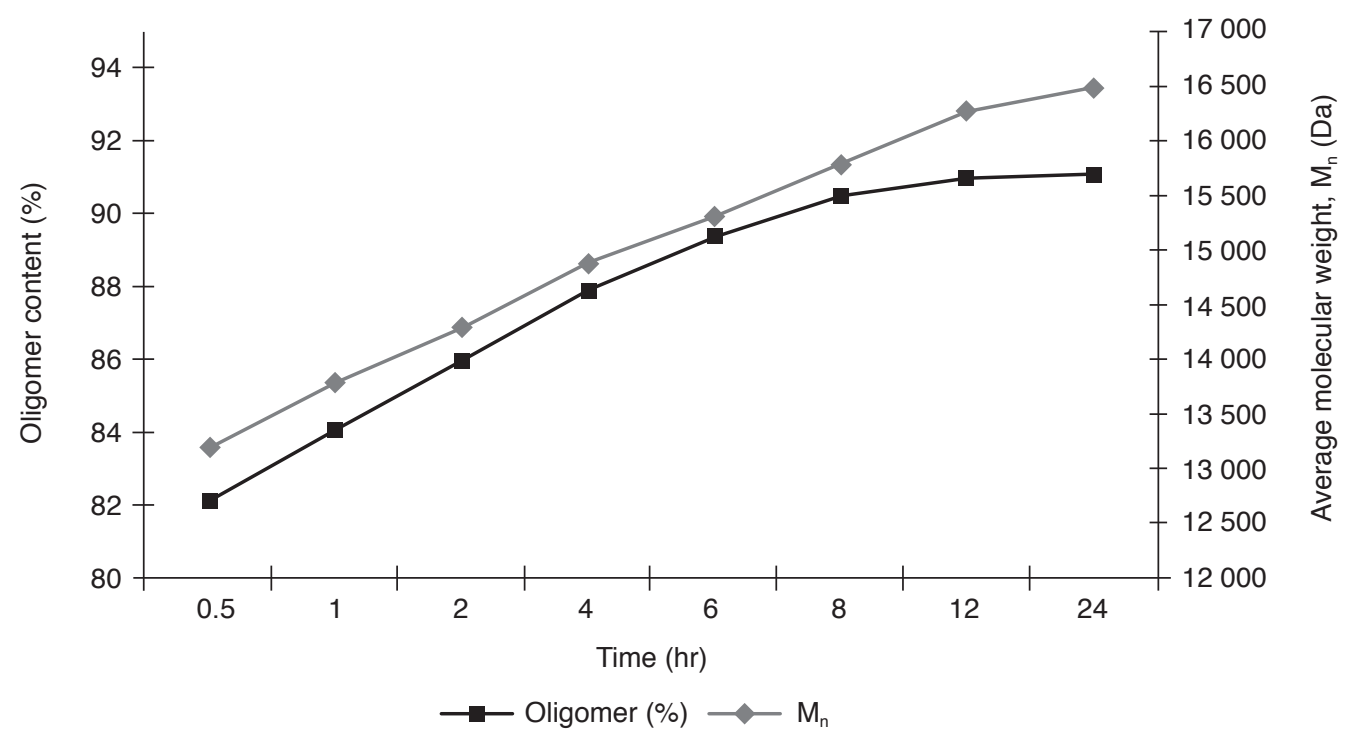

Note: Reaction parameters: temperature: $25^{\circ} \mathrm{C}$; reactant concentration: $1.87 \times 10^{-4} \mathrm{~mol} \mathrm{ml}^{-1}$; mol equivalent of $\mathrm{BF}_{3}$. $\mathrm{Et}_{2} \mathrm{O}: 0.035$.

Figure 3. Graph to show the oligomerisation of epoxidised palm oiein (EPOo) against time to produce oligomerised palm olein polyol $(\mathrm{OPO} O \mathrm{P})$ conducted at $25^{\circ} \mathrm{C}$ for $24 \mathrm{hr}$. 
oligomer content started to level out (plateau) after $24 \mathrm{hr}$ reaction, indicating that the polymer content will not increase significantly with a longer reaction time.

Matrix-assisted laser desorption/ionisation time-of flight (MALDI-TOF) mass spectrometry (MS) analysis confirmed the oligomerisation of EPOo to form OPOoP with dimer, trimer and tetramer of OPOoP clearly detected (Figure 4). The repeating unit of OPOoP, which has a molecular weight of $890 \mathrm{Da}$ is shown in Figure 1. Furthermore, the mass spectrum in Figure 4 also indicated the heterogeneity of molecular structure of OPOoP, where dimer, trimer and tetramer of OPOoP were represented by a cluster of peaks. The heterogeneity of molecular structure originated from the mixture of triacylglycerols that constitute POo as well as from the random oligomerisation of assorted epoxidised triacylglycerols. The higher oligomers were not detected by MALDI-TOF-MS due to detector saturation caused by continuous stream of particles impacting the detector that causes a loss of sensitivity at higher molecular masses.

The reaction was also followed by ${ }^{1} \mathrm{H}$ NMR analysis and the following Figure 5 shows the overlaid ${ }^{1} \mathrm{H}$ NMR spectrum of EPOo at 30 min, 6 $\mathrm{hr}, 12 \mathrm{hr}$ and $24 \mathrm{hr}$ of reaction time. The ${ }^{1} \mathrm{H}$ NMR analysis showed that the epoxide group of EPOo (2.80-3.10 ppm) was ring opened to ether and hydroxyl functionality (3.30-3.65 ppm) as shown in Figure 5.

\section{Oligomerisation of EMO in Solvent}

Based on the results from the experiments conducted on EPOo, EMO was oligomerised with the same catalyst $\left(\mathrm{BF}_{3} \cdot \mathrm{Et}_{2} \mathrm{O}\right)$ in hexane to yield oligomerised methyl oleate polyol (OMOP). The properties of OMOP made from a set of experiments are shown in Table 1.

Referring to Table 1 , reaction conducted with 0.05 $\mathrm{mol}$ of $\mathrm{BF}_{3} \cdot \mathrm{Et}_{2} \mathrm{O}$ per mol of epoxide group (Entry 8) was able to yield $85 \%$ of OMOP from EMO. Similar result was achieved when higher amount of catalyst (0.1 mol equivalent) was used (Entry 9). When lower amounts of catalyst was used ( 0.03 mol equivalent), the yield of OMOP dropped to 57\% (Entry 7).

High resolution mass spectrometry (HRMS) analysis showed that the OMOP has an average molecular weight of $977 \mathrm{Da}$, which corresponded to the sodium adduct of trimer of EMO linked by ether functional group (Figure 6). The repeating unit of OMOP has a molecular weight of $312 \mathrm{Da}$.

GPC analysis of starting material (EMO) showed an average molecular weight of about $500 \mathrm{Da}$. GPC analysis of OMOP (Table 1, Entry 8) showed an average molecular weight of about 1500 $\mathrm{Da}$, which indicated that the OMOP was mainly a trimer of EMO. The HRMS data supports the GPC analysis results.

The following Figure 7 shows the overlaid ${ }^{1} \mathrm{H}$ NMR spectrum of EMO and OMOP. Referring to the ${ }^{1} \mathrm{H}$ NMR spectrum, the epoxide group of EMO

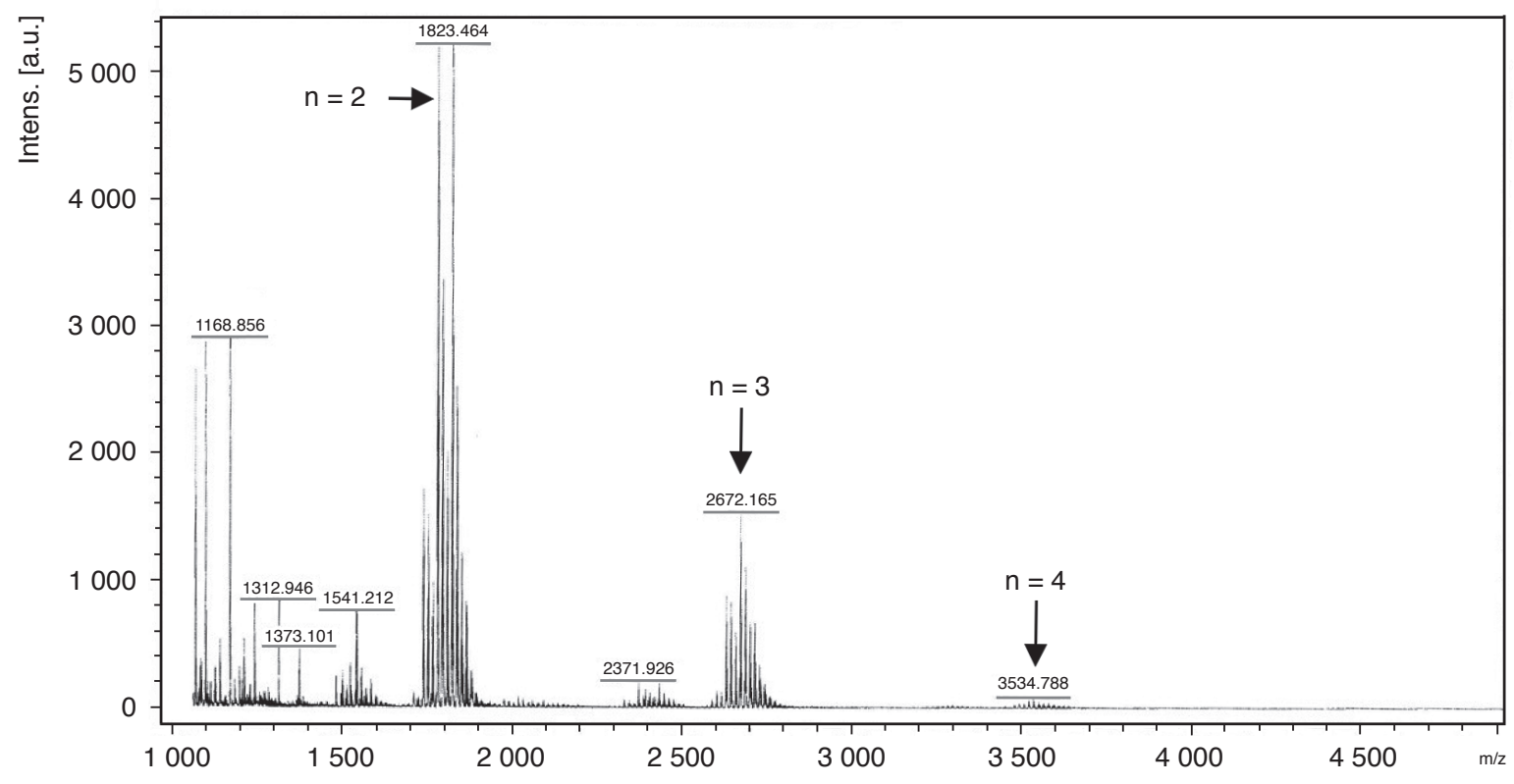

Note: $\mathrm{n}$ - number of repeating unit that could be 1, 2, 3 or 4 .

Sample for MALDI-TOF was obtained from reaction conducted using the following reaction parameters: temperature: $25^{\circ} \mathrm{C}$; reactant concentration: $1.87 \times 10^{-4} \mathrm{~mol} \mathrm{ml}^{-1}$; mol equivalent of $\mathrm{BF}_{3}$. $\mathrm{Et}_{2} \mathrm{O}: 0.035$.

Figure 4. Matrix-assissted laser desorption/ionisation time-of flight-mass spectrometry (MALDI-TOF-MS) spectrum of oligomeric polyol (OPOoP) by using 2,5-dihydroxy benzoic acid as the matrix in the analysis. 


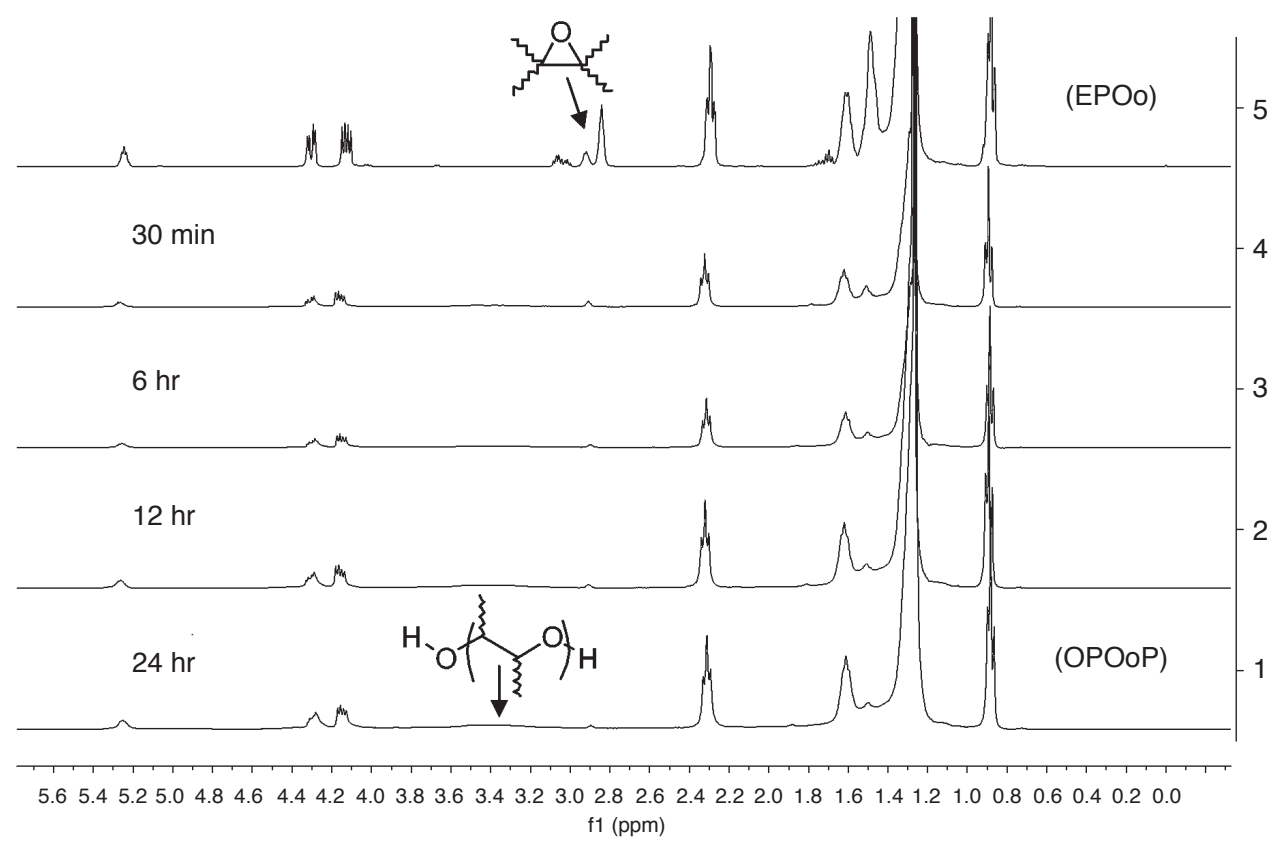

Figure 5. Overlaid $400 \mathrm{MHz}^{1} \mathrm{H} N \mathrm{MR}$ of epoxidised palm olein (EPOo) and reaction mixture at certain reaction time in $C D C l_{3}$. Reaction was conducted using the following reaction parameters: temperature: $25^{\circ} \mathrm{C}$; reactant concentration: $1.87 \times 10^{-4} \mathrm{~mol} \mathrm{ml}^{-1}$; mol equivalent of $\mathrm{BF}_{3}$. Et ${ }_{2} \mathrm{O}: 0.035$.<smiles>CCCCCCCCCCC(OC(CCCCCCCCC(C)=O)C(O)CCCCCCCCC)C(CCCCCCCCCC(C)=O)OC(CCCCCCCC)C(O)CCCCCCCCC(C)=O</smiles>

Note: Sample was obtained from reaction conducted using the following reaction parameters: temperature: $25^{\circ} \mathrm{C}$; reactant concentration: $16 \times 10^{-4} \mathrm{~mol} \mathrm{ml}^{-1}$; mol equivalent of $\mathrm{BF}_{3} . \mathrm{Et}_{2} \mathrm{O}$ : 0.05; reaction duration $24 \mathrm{hr}$.

Figure 6. Idealised trimer of epoxidised methyl oleate (EMO) linked by ether group.

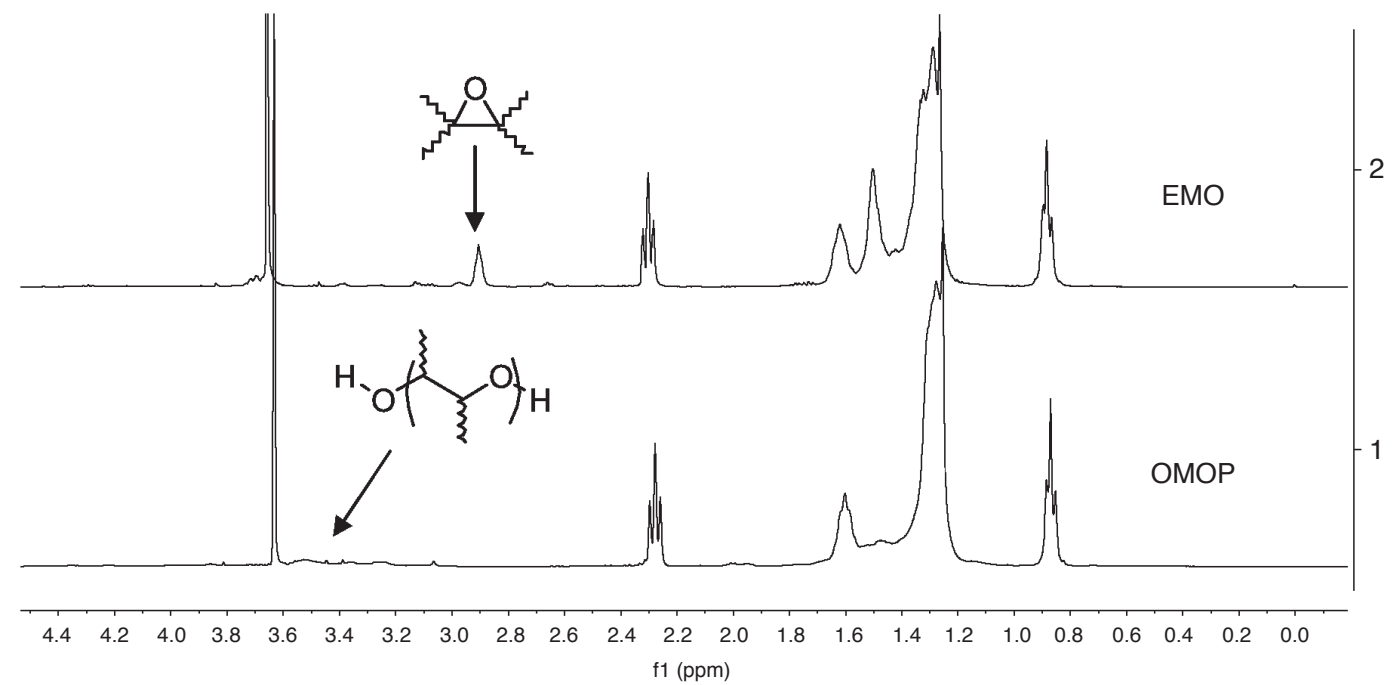

Figure 7. Overlaid ${ }^{1} \mathrm{H} N \mathrm{NR}$ spectrum of epoxidised methyl oleate (EMO) and oligomerised methyl oleate polyol (OMOP) in $\mathrm{CDCl}_{3}$. Reaction was conducted using the following reaction parameters: temperature: $25^{\circ} \mathrm{C}$; reactant concentration: $16 \times 10^{-4} \mathrm{~mol} \mathrm{ml}^{-1}$; mol equivalent of $\mathrm{BF}_{3}$. Et $t_{2} \mathrm{O}: 0.1$; reaction duration $24 \mathrm{hr}$. 
at 2.86-3.14 ppm was ring opened to yield ether and hydroxyl functionalities (3.20-3.60 ppm) of the OMOP.

\section{Optimised Properties of OPOoP and OMOP}

Table 2 shows the optimised properties of oligomeric polyols made from EMO and EPOo respectively. These polyols were produced through optimum reaction conditions that gave highest yield for each type of oligomeric polyols. The prepared oligomeric polyols were analysed using ${ }^{1} \mathrm{H}$ NMR and GPC as well as wet analyses.

When oligomeric polyols made from respective EMO and EPOo were compared, EMO that has one epoxide group per molecule would not form cross-linked polymer even when catalysed by 0.1 mol equivalent of $\mathrm{BF}_{3} \cdot \mathrm{Et}_{2} \mathrm{O}$ and $\mathrm{EMO}$ gave good yield of oligomeric polyol $(85 \%)$. While for EPOo that has an average of two epoxide groups per molecule, the amount of catalyst used must be less than $0.04 \mathrm{~mol}$ equivalents of $\mathrm{BF}_{3} \cdot \mathrm{Et}_{2} \mathrm{O}$ to avoid the formation of cross-linked products. The higher epoxide content led to higher cross-linking during the oligomerisation reaction as shown by the significantly higher $M_{w}$ value and hence the higher PDI value of the OPOoP. The higher epoxide functionality also contributed to the slightly higher yield of the OPOoP as well as the higher hydroxyl values.

Referring to Table 2, the hydroxyl values of the prepared oligomeric polyols were in between 35 to $45 \mathrm{mg} \mathrm{KOH} \mathrm{g}^{-1}$ sample, depending on the starting material. In general, epoxidised oil with higher epoxide functionality would produce a higher hydroxyl value because the hydroxyl functionality originated from epoxide group through ring opening reaction. Thus, the hydroxyl functionality of OMOP is about two because EMOP has one epoxide group per molecule. Meanwhile, the EPOo that has on average two epoxide groups per molecule shall generates four hydroxyl groups per molecule for OPOoP. It is noteworthy that the low acid values indicate little hydrolysis ( $1 \mathrm{mg} \mathrm{KOH} \mathrm{g}^{-1}$ sample) of the products during reaction and low acid value is a desirable feature of polyol for PU application.
The novel OPOoP polyol made from POo is a viscous liquid at $25^{\circ} \mathrm{C}$. The $\mathrm{OPOoP}$ is an oligomeric polyol, which consists of a few unit of hydroxylated triacylglycerol linked by ether functionality that exhibits an average molecular weight of $16000 \mathrm{Da}$. Based on its hydroxyl value and molecular weight, the OPOoP should be suitable to be used as polyol for making flexible PU products. In comparison to a similar study reported by Liu et al. (2010), the epoxide ring opening oligomerisation of epoxidised soyabean oil with $\mathrm{BF}_{3} \cdot \mathrm{Et}_{2} \mathrm{O}$ in dichloromethane generated solid cross-linked polymer that was insoluble in many common solvents, which render it not suitable for PU applications.

Furthermore, a majority of vegetable oilbased polyols reported in the literature ( $\mathrm{Li}$ et al., 2015; Maisonneuve et al., 2016) are monomeric polyols which are basically a single unit of a polyhydroxylated triacylglycerol molecule that have an average molecular weight of $1000 \mathrm{Da}$. These polyols are suitable for making rigid PU products due to their molecular weight and polyhydroxylated nature, which are similar to the properties of typical petroleum based polyols used for making rigid PU products (Ionescu, 2005).

The OMOP polyol consists of oligomers of methyl oleate linked by ether groups that can be classified as a polyether diol with an average molecular weight of $1900 \mathrm{Da}$. The hydroxyl value and average molecular weight of OMOP indicated that it could potentially be used as an alternative petroleum-based polyols for making elastomeric PU such as coatings and adhesives, which predominantly use polyester polyols as raw material (Prisacariu, 2011). In addition, the synthesis steps taken to make OMOP are relatively less hazardous as compared to similar study reported by Lligadas et al. (2006), which employed extremely toxic and corrosive fluoroantimonic acid $\left(\mathrm{HSbF}_{6}\right)$ as catalyst.

\section{PU Made from Palm-based Oligomeric Polyols}

The synthesised oligomeric polyols were reacted with 4,4'-MDI and yielded quantitative amounts of PU samples. In addition, the oligomeric polyols were also mixed with higher molecular weight diols

TABLE 2. OPTIMISED PROPERTIES OF OLIGOMERIC POLYOLS MADE FROM EPOXIDISED (EPOo) AND EPOXIDISED METHYL OLEATE (EMO)

\begin{tabular}{|c|c|c|c|c|c|c|c|c|}
\hline \multirow[b]{2}{*}{ [R] } & \multirow[b]{2}{*}{ [OP] } & \multirow[b]{2}{*}{ Mol eq. } & \multirow[b]{2}{*}{ Yield $(\%)$} & \multicolumn{3}{|c|}{ GPC } & \multirow[b]{2}{*}{ OHV } & \multirow[b]{2}{*}{ AV } \\
\hline & & & & $\mathrm{M}_{\mathrm{w}}(\mathrm{Da})$ & $M_{n}(D a)$ & PDI & & \\
\hline EMO & OMOP & 0.10 & 85 & 2100 & 1900 & 1.10 & 35 & 0.7 \\
\hline EPOo & OPOoP & 0.035 & 89 & 58200 & 16100 & 3.61 & 45 & 0.9 \\
\hline
\end{tabular}

Note: [R] - reactant; mol eq. - mol equivalent of $\mathrm{BF}_{3} \cdot \mathrm{Et}_{2} \mathrm{O}$; GPC - gel permeation chromatography; $\mathrm{M}_{\mathrm{w}}$ - weight average molecular weight; $\mathrm{M}_{\mathrm{n}}$ - number average molecular weight; PDI - polydispersity index; $\mathrm{OHV}$ - hydroxyl value (mg KOH g-1); $\mathrm{AV}$ - acid value $\left(\mathrm{mg} \mathrm{KOH} \mathrm{g}^{-1}\right)$. OMOP - oligomerised methyl oleate polyol. OPOoP - oligomerised palm olein. [OP] - oligomeric polyol. 
namely PEG 3350 (average molecular weight of 3350 Da) and these polyols mixtures were reacted with MDI to produce PU. Each oligomeric polyol was mixed with a certain amount of PEG to yield PU samples with $60 \%$ hard segment. The ratio between the isocyanate group (NCO) and the hydroxyl group $(\mathrm{OH})$ was kept at 1.05 to $1(\mathrm{NCO} / \mathrm{OH}$ ratio $=1.05)$ in order to ensure that all the hydroxyl groups of the palm-based oligomeric polyols were fully reacted and the PU samples were fully cured when the excess isocyanate group reacted with moisture from the air.

The PU sample (OMOP-MDI) was made from OMOP and it was a paste at room temperature. On the other hand, the PU sample (OPOoP-MDI) made from OPOoP was a cross-linked polymer that formed solid at room temperature, indicating that polyol with three or higher hydroxyl groups per molecule is needed to enable the formation of network/cross-linked polymers.

The PU sample (OMOP-PEG-MDI) made from OMOP in combination with PEG was again a paste sample at room temperature. In contrast, the PU sample (OPOoP-PEG-MDI) made from OPOoP in combination with PEG was a solid polymer. Solid PU sample was also made from PEG alone as reference (abbreviated as PEG-MDI).

Tensile tests were carried out on these solid PU's in order to give a better picture about their strength and the test results of these solid PU's are shown in Figure 8. Furthermore, swelling test was conducted on each of the PU samples in order to determine the cross-link density by using the Flory-Rehner equation (Semsarzadeh et al., 2003). Table 3 shows the properties of these solid PU samples.

Referring to Figure 8 and Table 3, the control PU (PEG-MDI) made from only PEG and MDI showed significantly high tensile strength $(16 \mathrm{MPa})$ but low elongation $(20 \%)$. The high tensile of PEG-MDI comes from the intermolecular forces between the polymer chains of PEG as the PU can form a semicrystalline structure in which the crystalline chains can act as a physical cross-link in the polymer matrix (Oprea, 2011). The physical crosslink also restricted the flexibility of the polymer matrix that resulted in low elongation at break value. In contrast, the chemical cross-link density of PEG-MDI was near to zero because both the PEG and MDI are bifunctional linear molecules, which cannot form cross-linking chemically. Thus, the PEG-MDI sample completely dissolved in the test solvent (toluene).

TABLE 3. PROPERTIES OF POLYURETHANE (PU) SAMPLES MADE FROM OLIGOMERISED PALM OLEIN POLYOL (OPOOP) AND POLYETHYLENE GLYCOL (PEG) POLYOLS

\begin{tabular}{lccc}
\hline PU & $\begin{array}{c}\text { Tensile } \\
\text { strength } \\
\mathbf{( M P a )}\end{array}$ & $\begin{array}{c}\text { Elongation } \\
\text { at break } \\
\mathbf{( \% )}\end{array}$ & $\begin{array}{c}\text { Cross-link } \\
\text { density x 10 } \\
\left(\mathbf{m o l ~ c m}^{-3}\right)\end{array}$ \\
\hline PEG-MDI & 16.0 & 20 & 0.0 \\
OPOoP-MDI & 1.0 & 70 & 2.0 \\
OPOoP-PEG-MDI & 6.5 & 650 & 3.5 \\
\hline
\end{tabular}

Note: MDI - methylene diphenyl diisocyanate.

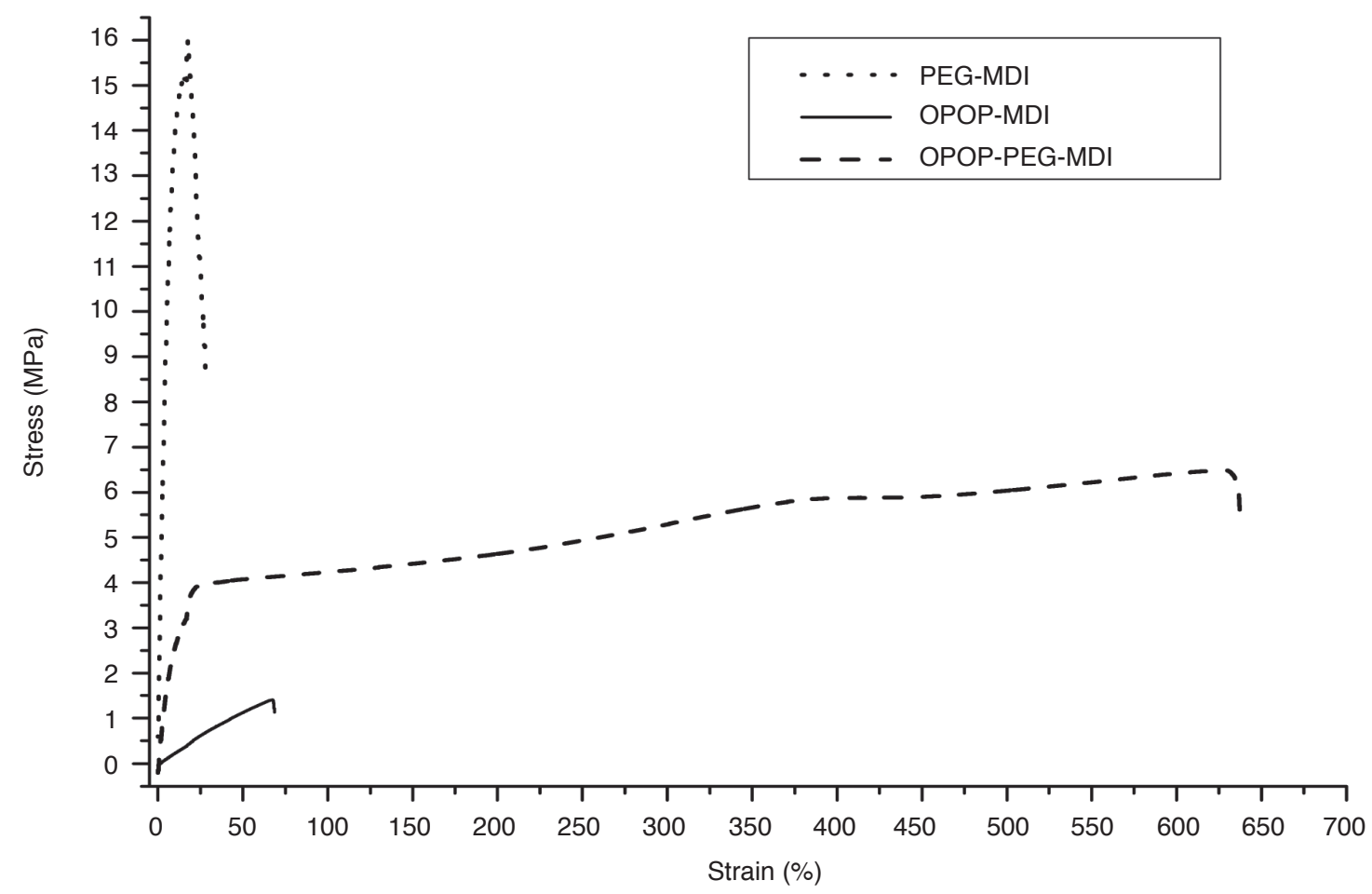

Figure 8. Stress-strain curves of polyurethane (PU) samples made from oligomerised palm olein polyol (OPOoP) and polyethylene glycol (PEG) polyols according to method EN ISO 529-4: 1997(CEN1997a). 
On the other hand, the PU sample OPOoPMDI showed a tensile strength of about 1.5 MPa and elongation at break close to $70 \%$. This is due to the branched structure of $\mathrm{OPOoP}$ that originated from palm olein's triacylglycerol structure and this branched structure prevent the formation of the semi-crystalline structure as observed in the PU made from PEG. Thus, the amorphous structure of the OPOoP-MDI did not contribute to the higher tensile strength. In addition, the hydroxyl value of OPOoP-MDI is relatively low in relation to its molecular weight as reflected by the measured crosslink density of OPOoP-MDI, which in combination with amorphous structure of the PU, contributed to the low tensile strength of the PU.

Nevertheless, when the OPOoP was mixed with PEG and reacted with MDI to form the PU sample OPOP-PEG-MDI; the tensile strength $(6.5$ $\mathrm{MPa}$ ) of OPOoP-PEG-MDI was found to be better than OPOoP-MDI. This higher tensile strength was contributed by the higher cross-link density found in the PU sample OPOoP-PEG-MDI $\left(3.5 \times 10^{-4} \mathrm{~mol}\right.$ $\mathrm{cm}^{-3}$ vs. $\sim 2.0 \times 10-4 \mathrm{~mol} \mathrm{~cm} \mathrm{~cm}^{-3}$ respectively). The most significant improvement on the properties of OPOoP-PEG-MDI as compared to OPOoP-MDI was the elongation at break. The OPOoP-PEGMDI was able to extend $650 \%$ its original length before breaking. In comparison, the PEG-MDI and OPOoP-MDI were only able to extend 20\% and $70 \%$, respectively. Referring to both tensile strength and elongation at break for OPOoP-PEGMDI, which point to the beneficial synergy from copolymerisation of petroleum-based polyol PEG with palm-based OPOoP to form PU (by reaction with MDI) as the PU sample formed from this mixture of polyols performed better than the PU made from either individual polyol respectively. Thus, the OPOoP has good potential to be used as polyol for elastic PU products.

\section{CONCLUSION}

POo and palm-based oleochemicals namely methyl oleate have been successfully converted to their corresponding epoxidised counterpart through epoxidation with hydrogen peroxide and tungsten catalyst. The prepared epoxidised oils can be oligomerised to yield oligomeric polyols through epoxide ring opening conducted in hexane in the presence of $\mathrm{BF}_{3} \cdot \mathrm{Et}_{2} \mathrm{O}$ without forming cross-linked polymers. The properties of oligomeric polyols were affected by the amount of catalyst, reaction temperature, reaction duration and the concentration of the epoxidised oils. The properties of oligomeric polyols also depended on the degree of epoxide of the epoxidised oils. The prepared oligomeric polyols can be used to make elastic PU products as they have hydroxyl groups that can react with diisocyanates.
The palm olein-based oligomeric polyol (OPOoP) in combination with PEG3350 can be made into PU sample (OPOoP-PEG-MDI) that exhibited good flexibility and tensile strength.

\section{ACKNOWLEDGEMENT}

The authors thank the Director-General of MPOB for permission to publish this article and for the funding of this research project. The authors would also like to express their gratitude to the personnel of Advanced Oleochemical Technology Division, MPOB who contributed to the completion of this study.

\section{REFERENCES}

AMERICAN OIL CHEMISTS' SOCIETY (AOCS) (2009). Acid value (Te 1a-64); hydroxyl value (Cd 1360); oxirane oxygen (Cd 9-57). Official Methods and Recommended Practices of the American Oil Chemists' Society. $6^{\text {th }}$ Ed., AOCS Press, Champaign, Illinois, USA.

BAUMANN, $\mathrm{H}$; BUHLER, $\mathrm{M}$; FOCHEM, $\mathrm{H}$; HIRSINGER, $\mathrm{F}$; ZOEBELEIN, $\mathrm{H}$ and FALBE, J (1988). Natural fats and oils - renewable raw materials for the chemical industry. Angewandte Chemie International Edition in English, 27(1): 41-62.

COLES, S R; BARKER, G; CLARK, A J; KIRWAN, K; JACOBS, D; MAKENJI, K and PINK, D (2008). Synthetic mimicking of plant oils and comparison with naturally grown. Macromolecular Bioscience, 8(6): 526-532.

DESROCHES, M; ESCOUVIOS, M; AUVERGNE, R; CAILLOL, S and BOUTEVIN, B (2012). From vegetable oils to polyurethanes: synthetic routes to polyols and main industrial products. Polymer Reviews, 52(1): 38-79.

GUO, A; CHO, Y J and PETROVIC, Z(2000). Structure and properties of halogenated and nonhalogenated soy-based polyols. J. Polymer Science: Part A: Polymer Chemistry, 38(21): 3900-3100.

HUBER, G W; CHHEDA, J N; BARRETT, C J and DUMESIC, J A (2005). Production of liquid alkanes by aqueous-phase processing of biomass-derived carbohydrates. Science, 308(5727): 1446-1450.

IONESCU, M (2005). Chemistry and Technology of Polyols for Polyurethanes. Rapra Technology Limited, Shawbury, Shrewsbury, UK. p. 55-321.

LI, Y B; LUO, X L and HU, S J (2015). Bio-based Polyols and Polyurethanes. Springer briefs in green chemistry 
for sustainability. Springer International Publishing AG, Switzerland. p. 19-31.

LIU, Z S and ERHAN, S Z (2010). Ring-opening polymerization of epoxidzied soybean oil. J. Amer. Oil Chem. Soc., 87(4): 437-444.

LLIGADAS, G; RONDA, J C; GALIA, M; BIERMANN, U and METZGER, J O (2006). Synthesis and characterization of polyurethanes from epoxidized methyl oleate based polyether polyols as renewable resources. J. Polymer Science: Part A: Polymer Chemistry, 44(1): 634-645.

MAISONNEUVE, L; CHOLLET, G; GRAU, E and CRAMAIL, H (2016). Vegetable oils: a source of polyols for polyurethane materials. Oilseeds and Fats, Crops and Lipids, 23(5): D508.

MEIER, M A; METZGER, J O and SCHUBERT, U S (2007). Plant oil renewable resources as green alternatives in polymer science. Chemical Society Reviews, 36(11): 1788-1802.

OPREA, S (2011). Effect of the long chain extender on the properties of linear and castor oil cross-linked PEG-based polyurethane elastomers. J. Materials Science, 46(7): 2251-2258.

PRISACARIU, C (2011). Polyurethane Elastomers, from Morphology to Mechanical Aspects. SpringerWein, New York, USA. p. 12-14.

RAGAUSKAS, A J; WILLIAMS, C K; DAVISON, B H; BRITOVSEK, G; CAIRNEY, J and ECKERT, C A (2006). The path forward for biofuels and biomaterials. Science, 311(5760): 484-489.

SEMSARZADEH, $\mathrm{M}$ A and NAVARCHIAN, A $\mathrm{H}$ (2003). Effects of $\mathrm{NCO} / \mathrm{OH}$ ratio and catalyst concentration on structure, thermal stability, and crosslink density of poly(urethane-isocyanurate). J. Applied Polymer Science, 90(4): 963-972. 